\title{
ALF ROSS AND HIS LEGAL PHILOSOPHY
}

\author{
Olexij M. Meteňkanyč \\ Comenius University in Bratislava, Faculty of Law
}

\begin{abstract}
The article has the ambition to present basic information of Alf Ross's legal philosophy, focusing on his understanding of validity of law, concept of rights, coercion in law, as well as the purpose of the legal science from his point of view as a representative of Scandinavian Legal Realism. In addition, within the article principal facts concerning life of Alf Ross and also list of his most important publications are presented.
\end{abstract}

Key words: Alf Ross, Scandinavian Legal Realism, concept of law, validity of law, legal science

\section{INTRODUCTION}

"In a way I am tempted by a subject in the philosophy of law because it is there that great thoughts, a philosophy of life, can be found and one does not just suffocate in details. But such a study has never been written in Denmark. It would, literally speaking, be a new passion here. Will anybody read it? It does not "lead" to anything either. Do I care? Can I? Am I strong?"

Alf Ross ${ }^{1}$

Scandinavian Legal Realism is specific legal-philosophical direction that seeks to discover the "real" nature of law, explores how the law (legal system) actually works and on what is based on. It is necessary to add that Czech and Slovak expert studies and papers usually refer to legal realism only to a very small extent, denoting it as non-normative, sociological or, in some specific cases, as an "exotic" or "mystical" approach to the law. ${ }^{2}$ However, Scandinavian Legal Realism is becoming popular amongst current foreign scholars and we can mention many well-known Scandinavian great philosophers and philosophers of law such as Axel Hägerström, Anders Vilhelm Lundstedt or Karl Olivecrona that are recognized by contemporary legal philosophers. Nevertheless, it is Danish legal philosopher Alf (Niels Christian) Ross who is internationally recognized as the best-known representative of Scandinavian Legal Realism. In fact, we believe that very term "Scandinavian" Legal Realism was created to incorporate both Axel Hägerström’s Uppsala School (and his disciples, like Olivecrona and Lundstedt) and Alf Ross legal philosophy. Otherwise, this direction could be labelled as Swedish Legal Realism or simply Legal Realism of Uppsala School. It was his contribution to Scandinavian Legal Realism that from our perspective made this direction internationally well-noted in the world of legal philosophy, particularly with his book On Law and Justice (1953), which is his masterpiece. So, let's find out more about this fellow...

EVALD, J.: Alf Ross - a life. Copenhagen: DJøF Publishing, 2014, p. 14.

2 For example see works: SOBEK, T.: Nemorální právo. Praha: Ústav státu a práva, 2010, p. 164 and the following; SOBEK, T.: Právní myšlení : Kritika moralismu. Praha: Ústav státu a práva, 2011, p. 319 and the following; COLOTKA, P. - KÁČER, M. - BERDISOVÁ, L.: Právna filozofia 20. storočia. Praha: Leges, 2016, p. 90 and the following; KUBŮ, L. a kol.: Dějiny právní filozofie. Olomouc: UPOL, 2002, p. 153 and the following; BRÖSTL, A.: Frontisterion. Bratislava: KALLIGRAM, 2009, p. 243 and the following. 


\section{CURRICULUM VITAE IN SUMMARY}

Alf Ross was born on 10 June 1899 in Copenhagen, the son of a civil servant in a government department. He graduated from high school in 1917. His first choice was to study at the Technical University, but he left it after one term and turned to law. He finished his legal studies in the summer of 1922 with remarkable results, obtaining the rare distinction then called laudabilis et qvidem egregie. $^{3}$

In 1923, Ross set out on a study tour which lasted two and a half years. In this same year he married Else-Merete Helweg-Larsen, a student at the Faculty of Humanities, who later became a high school teacher. She was a Member of Parliament in 1960-73, representing a small liberal party which held considerable influence over the formation of political majorities after general elections.

From information given by Ross himself, it seems his interest in the philosophy of law arose during mentioned trip, and he was particularly inspired by Professor Hans Kelsen in Vienna. The result of his studies abroad was the treatise Theorie der Rechtsquellen (A Theory of the Sources of Law).

Alf Ross wrote many diaries during periods of his life and also interesting source of his thoughts are letters to his wife or his colleagues and friends. This material makes it possible to give Alf Ross' perspective on his life, seen 'from below', or rather from 'within.'

Until 1935 he had modest and, professionally, rather unrewarding jobs, such as assistant at the law library or secretary to the National Council of Child Welfare. He also received a scholarship granted by the Carlsberg Foundation to the University of Copenhagen. When Ross finally became a member of the Faculty of Law in Copenhagen in 1935, he was seen as a strange, but colourful bird in the quiet garden of legal science. At the same time, some must have known or felt that this was a scholar promising something new. In its report on the applicants, the faculty was wise enough not to depict Ross as a writer sending half intelligible messages from his ivory tower.

Ross became a professor of International Law in Copenhagen in 1938. In 1942 Ross published his Loerebog i Folkeret (Textbook on International Law). It appeared later in many editions and was translated into English and German. International Law was described by Ross as " a conventional, non-coercive order with a secondary stamp of law." He added that this applied to International law in its current shape. According to mentioned concept, International Law was an order between selfgoverning societies which might very well be equipped with organization, authorities and means of force. A development of this kind was highly desirable and became of renewed concern in the years after the Second World War.

Teaching International Law was, for nearly 14 years, Alf Ross' platform for dealing with general problems of legal theory and methodology. As an author he was free to write on whatever subject he wished. He thus produced a large amount of articles, which were later included in one

3 WAABEN, K.: Alf Ross 1899-1979: A Biographical Sketch. In: EJIL, 2003, Vol. 14, No. 4, p. 661.

4 It is also worth to mention diaries of Alf Ross's wife, Else-Merete Ross, who describes Alf Ross in some places in totally different perspective than it is used to by scholars. But her diaries should be taken with caution, because some letters were full of negative emotions. Alf and Else-Merete had temperamental and vivid marriage. See more in EVALD, J.: Alf Ross - a life. Copenhagen: DJØF Publishing, 2014, p. 15.

5 WAABEN, K.: Alf Ross 1899-1979: A Biographical Sketch. In: EJIL, 2003, Vol. 14, No. 4, p. 666. 
form or another in his main book on jurisprudence. In 1953 Ross published a book Om Ret og Retferdighed (On Law and Justice), the opus magnum of Danish jurisprudence and his masterpiece. He wrote, appropriately so, that the discipline of jurisprudence or legal philosophy had long played a poor role in the teaching of law. This book was intended to be a textbook for law students, but proved to be far more than that. It became world-known and to these days it is used by legal philosophers.

Alf Ross served as a judge on the European Court of Human Rights from 1959 to 1972. These were not busy years in the Court, since very few cases were referred to it by the Commission of Human Rights. Ross was critical of this practice and wrote an article on it. However, a colleague on the Court persuaded him not to publish the article and it thus exists in a limited number of private reprints.

Ross believed in democracy and in a liberal economy. He never played an active part in political life. In 1945 he had proclaimed unreserved support for the Social Democrats and a belief in socialism without Marxism and communism. Twenty years later he declared himself unable to vote for that party because he feared it would enter a coalition with the smaller and more leftist Socialist Party.

In January 1979 Alf Ross had a surgery because of prostate cancer. ${ }^{6}$ He regained his strength quickly and felt strong enough to write a comforting letter to the Swedish professor of law Ivar Strahl, who was in hospital, and he also wrote to his friend Richard M. Hare with professional advice. Nonetheless, Alf Ross suffered from cancer and in some letters he described the radiation therapy, pains and fatigue, his worries and his depression. Especially after the death of his wife Else-Merete Ross ${ }^{7}$ he built a more intimate relationship with the Polish Ija Lazari-Pawlowska, professor of ethics at the Department of Philosophy in Lodz.

Alf Ross and Ija Lazari-Pawlowska corresponded frequently and Ross in many letters explained Ija Lazari-Pawlowska how serious his situation was. In a letter dated $30^{\text {th }}$ August Ija Lazari-Pawlowska gave vent to her despair. "I am aware of how serious the situation is. I am aware that one day I may really lose you and I cannot understand it. I am in despair. When you were well I always believed that we still have many years ahead of us... stay, Alf and have courage." 8 Alf Ross never read this letter because he died on $16^{\text {th }}$ August 1979 at the age of eighty.

\section{$3 \quad$ LIST OF PUBLICATIONS OF ALF ROSS}

Alf Ross wrote a large amount of books, textbooks, articles etc., especially within his academic period of time. We can mention the most important ones:

- Kritik der sogenannten praktischen Erkenntnis: Zugleich Prolegomena zu einer Kritik der Rechtswissenschaft (Critique of the so-called practical knowledge: With prolegomena towards a critique of legal science) from the 1933 ,

- Concerning Reality and Validity in Legal Procedure: a Critique of the Fundamental Concepts of Theoretical Law (1934),

\footnotetext{
EVALD, J.: Alf Ross - a life. Copenhagen: DJØF Publishing, 2014, p. 353. She died on the $1^{\text {st }}$ March 1976.

EVALD, J.: Alf Ross - a life. Copenhagen: DJØF Publishing, 2014, p. 354.
} 
- Towards a Realistic Jurisprudence: A Criticism of the Dualism in Law (1946),

- Why Democracy? (1946),

- Constitution of the United Nations (1950),

- On Law and Justice (1953, in English appeared in 1958),

- Tû-tû, Harvard Law Review vol. 70, Issue 5, March 1957,

- Danish Constitutional Law (1959-1960),

- The United Nations, Peace and Progress (1963, in English appeared in 1966),

- Directives and Norms (1968),

- Crime and Punishment (1974),

- On Guilt, Responsibility and Punishment (1970, in English appeared in 1975).

Additionally to mentioned publications, Ross published many articles in newspapers and journals, especially following his retirement from the faculty in 1969, on subjects as varied as euthanasia, pornography, domestic and world politics, war crimes, and the concepts of normality and disease in medical science. Some of these articles were collected in a small volume called Demokrati, Magt og Ret (Democracy, Power and Law) from 1974. Ross seemed to have enjoyed turning his hand to the brief and more relaxed style of commenting on current issues. These essays gave a more varied impression of what occupied Ross' mind as a private person, a citizen and an observer of the world around him.

\section{ALF ROSS'S LEGAL PHILOSOPHY}

\subsection{Did Alf Ross see himself as a philosopher or a legal scholar?}

Did Alf Ross consider himself a philosopher or a legal scholar? Occasional letters to and from colleagues and friends show that Alf Ross considered this himself and that depending on to whom he was writing he saw himself as either philosopher or legal scholar. In a letter dated $14^{\text {th }}$ December 1932 to the German philosophy professor in Berlin Arthur Liebert, Alf Ross wrote that he could not understand why Liebert did not consider him to be a philosopher but instead one who prepares the road to philosophy. Alf Ross did not contest this statement, being of the opinion that he was closer to science than pure philosophy. Liebert had expressed the opinion that fundamentally philosophers were terribly rude and Alf Ross' comment on this was that he was not courageous enough to be rude. Later on in life Alf Ross considered himself to be both a philosopher and a legal scholar and he went as far as claiming that the foundation for any new advance in legal philosophy had to be made by people who had an academic background in both. Naturally he thought of himself.

"I do not know of a philosophical fundamental position that I can adopt without having to admit to myself that the exact opposite position is also defensible. Therefore it is hopeless. I am lacking that ability to be one-sided that on its own can provide satisfaction and confidence. " $\mathrm{His}$ statement about the lack of one-sidedness is interesting because it is in such a pronounced contrast to the vigour with which he defended his own philosophical points of view.

9 Ibid., p. 109-112. 
His academic life was influenced especially by two philosophers - Hans Kelsen ${ }^{10}$ and Axel Hägerström. ${ }^{11}$

After obtaining a law degree in Copenhagen (in 1922), Ross received a scholarship to study abroad and spent most of that period in France and England, and in particular in Austria in 1923. Here Ross was exposed both to Hans Kelsen's ideas and to the Viennese philosophical circle (though he did not come into contact with logical empiricism until around 1930). During his stay in Vienna, Ross completed a manuscript titled "Theorie der Rechtsquellen" (A Theory of the Sources of Law) which he submitted as a thesis for a doctor-of-law degree at the University of Copenhagen in 1926, only to be rejected. Ross thus decided to contact Hägerström and submit the manuscript as a thesis for a doctor-of-philosophy degree at the University of Uppsala.

Ross never disavowed his debt to Hägerström. To be sure, like many other Scandinavian legal realists, he wound up departing from Hägerström's teachings - he did so by addressing the concerns arising out of logical positivism (as by taking into account the central role of the philosopher in clarifying legal language) - and like those realists, he nonetheless continued to look up to Hägerström, the teacher "who opened my eyes to the emptiness of metaphysical speculations in law and morality." 12

However, unlike Olivecrona and Lundstedt, Ross never followed Hägerström's teachings faithfully (nor did he claim to do so). Instead, he enriched the legal realist framework by incorporating into it insights coming from various philosophies and legal theories, primarily logical positivism and some aspects of Kelsenian legal theory and, to some extent, American legal realism. ${ }^{13}$

Despite this multiplicity of sources from which Ross proceeded, he is correctly considered a proponent of Scandinavian Legal Realism, this on account of the attention he devoted to the nature of legal science, focusing in particular on the question whether its status is cognitive or non-cognitive.

10 He attended lectures by Professor Hans Kelsen on legal philosophy at the University of Vienna, during trip around Europe, including cities like Paris, Vienna, London and Berlin. The encounter with Hans Kelsen developed into a life-long friendship, which is not strange when one considers that their lives had several similarities. First of all, Kelsen had an interest in philosophy, mathematics and physics and had planned to study these subjects. Secondly, Kelsen was a public supporter of the Social Democrat party. Thirdly, Kelsen was concerned with the philosophy of law and constitutional law. Fourthly, Kelsen had been accused of stealing his ideas from others. Fifth, Kelsen was involved in a mighty personal feud that left deep wounds. Sixth, Kelsen was known to be charming, but cruel when defending his legal theory, which often expressed itself in attacks on his critics. These are the reasons that make it relevant and interesting to study Kelsen's often turbulent life in more detail. Ibid., p. 68.

11 He devoted his first academic works to both of them, specifically Theorie der Rechtsquellen: Ein Beitrag zur Theorie des positiven Rechts auf Grundlage dogmenhistorischer Untersuchungen (A theory of the sources of law. Contribution to the theory of positive law on the basis of historical-dogmatical investigations was dedicated to Hans Kelsen and Kritik der sogenannten praktischen Erkenntnis: Zugleich Prolegomena zu einer Kritik der Rechtswissenschaft (Critique of the so-called practical knowledge: With prolegomena towards a critique of legal science) was dedicated to Axel Hägerström. See more in PATTARO, E. - ROVERSI, C.: Legal Philosophy in the Twentieth Century: The Civil Law World. Volume 12, Tome 2: Main Orientations and Topics. Berlin: Springer, 2016, p. 401-402.

12 ROSS, A.: On Law and Justice. London: Stevens \& Sons, 1958. The Scandinavians have always explicitly recognized, some more than others (Lundstedt more than Ross, for example), that their philosophical foundation lies in the Uppsala School and in particular in Hägerström's inquiries in the world of legal and moral philosophy. See more in BJARUP, J.: Skandinavischer Realismus: Hägerström - Lundstedt - Olivecrona - Ross (Scandinavian realism: Hägerström, Lundstedt, Olivecrona, Ross). Freiburg i. B. and München: Alber, 1978, p. 23-38.

13 See, for example, HART, H. L. A.: Scandinavian Realism. In: Cambridge Law Journal, 1959, vol. 17, no. 2, p. 237, where Hart depicts Ross as "an American realist in Scandinavia." 


\subsection{The Concept of Valid Law}

According to Ross, law is valid when it has the property of binding a certain community or certain legal actors, such as judges, to certain modes of behaviour, whatever behaviour the law itself may prescribe. Validity is a content-neutral concept. ${ }^{14}$ As legal realist, Ross believed that the source of validity needs to be sought outside the law, in the spatiotemporal coordinates of empirical reality. "Our object in determining the concept of law is not to spirit away the normative ideas, but to put a different interpretation on them, reading them for what they are, the expression of certain peculiar psycho-physical experiences, which are a fundamental element in the legal phenomenon." ${ }^{15}$ Simply: A legal norm is valid when is "in force". There are two empirical criteria that need to be met in order for a norm to be legally valid in the sense just specified:

- It must be recognized and followed by the majority of the community of addressees, ${ }^{16}$ and

- it must be felt by this majority to be "socially binding," as against being morally binding, so this second criterion serves the purpose of distinguishing law from morals. ${ }^{17}$

According to Ross, the definition of valid law consists of these two criteria, that is, by predicating validity on ( $i$ ) efficacy (the fact of a norm's being in force), and (ii) a social feeling of being bound by the norm. ${ }^{18}$

The first criterion, the efficacy criterion, is not something new in legal philosophy. It is also present in works of authors like Kelsen or Hart. By the contrast, much more debates and criticism raised to the second criterion - subjective or psychological criterion (feeling of being bound). The criticism was that this subjective factor makes it difficult to distinguish legal concepts from moral ones, since both are founded in the same feeling. Ross admitted that law and morals operate in the same way (on a psychological basis) and that to some extent they help each other in forcing people to act in certain ways. However, Ross emphasized that we have to differentiate between mode of operation and feelings behind the legal and the moral phenomenon. "Whereas the addressees of legal provisions obey the law saying to themselves, "I ought to act thus" (that is, "I have to"), the addressees of moral prescriptions follow those rules saying, "I must act thus."' 19 Later, Ross called former thinking as a formal legal consciousness, the later one called as material legal consciousness. ${ }^{20}$

To sum up, Ross understands law as "whatever complex of norms and concepts happens to be binding in society, regardless of the ideologies espoused in society." ${ }^{21}$ But the law is perceptive to its

14 This can be linked to Kelsen's theory, see, for example, KELSEN, H.: General theory of law and state. Trans. Anders Wedberg. Cambridge: Harvard University Press, 1945, 516 p. But whereas Kelsen rested validity on the basic norm, Ross did not understand validity as a property of law and of legal concepts that can be derived from the legal system itself. More in PATTARO, E. - ROVERSI, C.: Legal Philosophy in the Twentieth Century: The Civil Law World. Volume 12, Tome 2: Main Orientations and Topics. Berlin: Springer, 2016, p. 403.

15 ROSS, A.: Towards a Realistic Jurisprudence. Trans. A. I. Fausbøll. Copenhagen: Munksgaard, 1946, p. 48.

16 In particular by the majority of the judicial body.

17 ROSS, A.: On Law and Justice. London: Stevens \& Sons, 1958, p. 18, 34-38.

18 By this distinction, Ross believed that we can resolve one of the classical antinomies in legal philosophy, the antinomy between efficacy and obligatory force, in that the law is considered "at the same time something factual in the world of reality [efficacy] and something valid in the world of ideas [obligatory force].” Ibid., p. 38.

19 PATTARO, E. - ROVERSI, C.: Legal Philosophy in the Twentieth Century: The Civil Law World. Volume 12, Tome 2: Main Orientations and Topics. Berlin: Springer, 2016, p. 404.

20 ROSS, A.: On Law and Justice. London: Stevens \& Sons, 1958, p. 55.

21 See in PATTARO, E. - ROVERSI, C.: Legal Philosophy in the Twentieth Century: The Civil Law World. Volume 12, Tome 2: Main Orientations and Topics. Berlin: Springer, 2016, p. 405. 
political and social environment. Therefore the validity of law is important. Validity of law means that the law is "in force", in that it is observed and it is felt to be binding by the majority of its qualified addressees, especially important are judges and other law enforcement authorities.

\subsection{The Concept of Rights}

Ross's legal theory rests on fact that central element of law lies in its language. Ross (like other Scandinavian legal realists ${ }^{22}$ ) begins his inquiry by directly focusing on the different concepts and categories that constitute the essence of legal language: duties, property, damages, and, more important, rights. The language is in his view the primary mean through which legal rules are produced by a legal order and addressed to the community. But legal language has also one specific feature. Its point is not to describe the world of the IS (Sein) or that of the OUGHT (Sollen), ${ }^{23}$ nor does it describe an economically efficient reality or a relation of trust between the rulers and the ruled. Ross considers legal language as having a directive function. "Legal language is an instrument of social control directed at shaping or creating a certain situation, especially through the influence it exerts on human behaviour." 24

Through his investigations, Ross arrived at two concurrent ideas about the nature of law in general and of rights in particular. First, legal concepts, like that of rights, are in themselves detached from any system of moral, religious, or political values. The concept of rights is no more attached to moral or political values than is the expression $t \hat{u}$-t $\hat{u}$. Ross even published an article so titled. ${ }^{25}$ According to Ross, the legal concepts and categories constitutive of law do not even have an ontological dimension to begin with. "'Ownership," "claim," and other words, when used in legal language, have the same function as the word "tû-tû"; they are words without meaning, without any semantic reference, and serve a purpose only as a technique of presentation." 26 The law is just a complex of linguistic signs or symbols, and some words (such as rights) are used for the purpose of leading its addresses to behave or not to behave in certain way. Ross calls them directives and they are "utterances with no representative meaning, but with the intent to exert influence."27 The law as such is a system based on the use of linguistic or symbolic signs. And words as right work as a stimulus designed to enforce response from the members of community, especially persons with the power to force some behaviour, namely judges. ${ }^{28}$ According to Ross, the traditional constitutive concepts of legal language (concepts such as "rights" and "duties") are in themselves meaningless. Still, they acquire an authoritative status, that is, they become law, simply by virtue of their being set in a certain social

22 It is important to mention that the linguistic aspects of law are central to Lundstedt's and Olivecrona's inquiries too (due to the degree to which these two thinkers were influenced by Hägerström's historical analysis of the use of legal language and its fundamental role in explaining the binding nature of law). For instance see OLIVECRONA, K.: Becoming a king according to the old Swedish law: The rite of creating a king as a magic act. Lund: Lunds Universitets årsskrift, 1946. Ross was more influenced by other impacts, namely legal positivism, which shaped his legal thinking in significant ways. Example of the influence of logical positivism on Ross's work can be found in ROSS, A.: On Law and Justice. London: Stevens \& Sons, 1958, p. 67.

23 Kelsen's view, see more, for example, in CHOVANCOVÁ, J. - VALENT, T.: Filozofia pre právnikov (filozoficko-právne aspekty). Bratislava: Univerzita Komenského v Bratislave, Právnická fakulta, 2012, p. 147-148.

24 ROSS, A.: On Law and Justice. London: Stevens \& Sons, 1958, p. 8, 158-160.

25 ROSS, A.: Tû-Tû. In: Harvard Law Review, 1957, vol. 70, no. 5, p. 812-825.

26 Ibid., p. 819-821.

27 ROSS, A.: On Law and Justice. London: Stevens \& Sons, 1958, p. 8.

28 Ibid., p. 32-33. 
and political framework that, for example, makes words such as tû-tû meaningless, while making words like right or duty, by contrast, meaningful. ${ }^{29}$

Therefore, Ross believes that lawmaker has to enact the new law that lead to results. So, this new law has to be expressed in a legal language that in most cases shares the values of the majority of population. "Only in this way can the law's stimulus-and-reaction mechanism work properly, bringing its addressees to actually consider the new law to be binding." ${ }^{30}$ Summarizing, the concept of rights is a linguistic and socio-psychological tool used to influence human behaviour.

\subsection{The Coercion in Law}

There is one question that Ross tried to answer and it is: how the rules that are perceived as binding law (and hence as valid law) can be distinguished from those that are not? According to Ross the answer is coercion ${ }^{31}$ (this is the basic criterion on which rest the binding nature of legal rules). "By observing which rules come to bear in regulating social relations, we can single out the ones that actually affect or are likely to affect the way judges will decide a dispute." ${ }^{32}$ According to Ross, to claim that a certain legal rule is valid means simply to claim that the rule will most likely be felt to be binding in future decision-making, in effect claiming that the rule will play a decisive role as a reason that courts in the future will invoke in deciding whether or not to apply a coercive measure.

Then coercion plays a central role in shaping the very nature of law. Ross views valid law as "coercive system of rules regulating the institutional use of violence, especially and in the first place by the judiciary." ${ }^{\text {33 }}$ Reality of law lies in its coercive nature. Law enables certain persons (especially judges) to use violence, but in a way that its addressees feel to be legitimate.

But not every legal rule is backed up by the threat of sanction. In every legal system there exists a series of norms whose legal validity does not rest on their being guaranteed by coercion. There are norms, like those on jurisdiction or competence (especially at the higher levels of the legal system), whose validity stands independently of any coercive means of enforcement. "These norms are valid (i.e. their addressees feel bound by them) not because force can be used to ensure compliance but precisely because, through a historical process of socio-psychological and linguistic reinforcement, these "rules without coercion" come to be viewed by those addressees, and in particular by the judges, as having cultural and political legitimacy."

\subsection{Law, Politics and Purpose of Legal Science}

In Ross's view, politics play essential role in its relation to the law. ${ }^{35}$ But there is a distinction between law and politics, although they both function as mediums through which people can be forced or

29 ROSS, A.: Tû-Tû. In: Harvard Law Review, 1957, vol. 70, no. 5, p. 818.

30 More in PATTARO, E. - ROVERSI, C.: Legal Philosophy in the Twentieth Century: The Civil Law World. Volume 12, Tome 2: Main Orientations and Topics. Berlin: Springer, 2016, p. 407.

31 Especially as implemented by the judiciary.

32 Ibid., p. 408.

33 Ibid., p. 409.

34 ROSS, A.: On Law and Justice. London: Stevens \& Sons, 1958, p. 78-80 or ROSS, A.: Towards a Realistic Jurisprudence. Trans. A. I. Fausbøll. Copenhagen: Munksgaard, 1946, p. 89-90, 108-112.

35 Actually, Ross devoted many pages of his most known book On Law and Justice on this topic. Particularly it is worth to mention chapters 13-17 of this book. See more in ROSS, A.: On Law and Justice. London: Stevens \& Sons, 1958. 
persuaded to behave in ways that they would not otherwise choose to behave in. Especially political order "aims at bringing about practical agreement by influencing an opponent's viewpoint through argumentation and persuasion." ${ }^{\text {"36 }}$ Lawmaking, contrary to political order, produces norms that are "effectively complied with because they are felt to be socially binding." ${ }^{37}$ In other words, "over time the law has acquired a certain degree of independent legitimacy, that is, a legitimacy resting more on the specific ways a certain rule is enacted and implemented than on its content-more on its normative features than on its political goals." ${ }^{38}$

However, there is a special requirement to lawmaking in order to work as a system that produces valid law. New statutes and judicial decisions have to embody the sociological and political values dominant in the community, reproducing them as law. But which values can be picked out as the ones that prevail in the community? According to Ross we ought to recognize all those values traditionally embraced by the democratic political model, and he strongly criticizes Lundstedt's idea of "social welfare," stressing that the latter tends to bring together a mixed bag of interests and values that by their very nature are divergent. ${ }^{39}$

We can say in agreement with Ross that the law is open to the political ideologies and among other things it means that we have to broaden the range of traditional sources of legally relevant materials the judges have to look to in deciding a legal issue. Therefore, very important are authoritative sources of law and they are ranked high in the hierarchy of sources.

Emphasis should be also placed in the interpretation of law. Legal interpreters must bring mentioned influence of the political world into balance with their legal education and with the directions imposed by existing ways of legal reasoning. The law as such, is to some extent autonomous and this is appreciated by Ross in some of his books. ${ }^{40}$ In Ross's view, "political discourse always tends to take divergent interests and values into account at the same time, in such a way as to wind up reasoning from compromised concepts like that of social justice." ${ }^{41}$ Political discussion does not lie on the plane of logic. It is argumentative, persuasive and its function is not to prove a truth, but to convince people that you are making right decisions in favour of community as such. By contrast, in legal reasoning there is no third solution between opposite values (e.g. it is valid or invalid law) and no compromise can be accepted (partial validity). The choice can only be between valid and invalid law, or, in Ross's terminology, between "the law in force and the rules of law that are not in force and hence (on a realist perspective) are not valid."

36 Ibid., p. 326.

37 Especially by the judges. Ibid., p. 34.

38 PATTARO, E. - ROVERSI, C.: Legal Philosophy in the Twentieth Century: The Civil Law World. Volume 12, Tome 2: Main Orientations and Topics. Berlin: Springer, 2016, p. 410.

39 See more in ROSS, A.: On Law and Justice. London: Stevens \& Sons, 1958, p. 289-296. Ross also notes that this sharing of values between legal and political orders is something that happens most of the time but not in all cases, recognizing that sometimes the law addresses technical issues that the majority of the population (or of the judges) have no knowledge of, and even if they did have some familiarity with such technicalities, they would not attach any value to them. Ibid., p. 372-377.

40 Ross's textbooks on constitutional law or in international law rarely make reference to political material as a source of law. When Ross takes up the reasoning developed within the political arena, he usually locates it under a specific and clearly separate heading dealing with the politics of law. In this sense, too, Ross's conception of legal science is influenced by Hans Kelsen. More in PATTARO, E. - ROVERSI, C.: Legal Philosophy in the Twentieth Century: The Civil Law World. Volume 12, Tome 2: Main Orientations and Topics. Berlin: Springer, 2016, p. 412.

41 Ibid., p. 412.

42 Ibid., p. 412. 
Ross believes that law should be a scientific discipline. To this end, it was necessary for the end result of legal science to be open to testing. So, it is important to produce statements by the legal science that could be assessed as correct or incorrect "in light of the empirical reality of the law in force, and in particular in light of judicial decisions." ${ }^{3}$ This should be main primary task of legal science.

A scientific investigation of the legal phenomenon is an investigation aimed at finding out what the law really is. Law is a powerful tool that the political institutions use to further their goals in society. Legal scholars therefore cannot disregard that development in the legal world, and in particular the making of new law. It would accordingly be self-limiting for the study of law to only rely on traditional analytical tools. Legal scholars must draw on history, political science, social science, psychology, sociolinguistics, and anthropology. ${ }^{44}$ Legal science is necessary a mixed discipline because "it is... impracticable to draw any sharp boundary line between cognitive pronouncements concerning valid law and legal political activity... Fundamentally, therefore, the cognitive study of law cannot be separated from legal politics." ${ }^{5}$

At the same time, however, Ross also promoted an idea of law as separate from politics. So, as much as he worked in the political order, he always did so as a lawyer and not as politician. According to Ross, "the role of the lawyer as legal politician is to function as far as possible as rational technologist," and legal scholars can intervene in the lawmaking process with mere "recommendations" offered to policy makers. ${ }^{46}$ His work and positions were those traditionally entrusted to those with the technical expertise of a lawyer: He served as professor of law and as legal consultant in the legislative process.

\section{CONCLUSION}

At the beginning of this article a quote from Alf Ross made early in his academic career was used, when he was not sure about his strength to continue in the area of legal philosophy, especially in Denmark, where his thoughts were revolutionary to the classical and orthodox legal thinking focusing on legal positivism. Nowadays, we know that Alf Ross made good decision to carry on and published many great books and articles that enriched legal philosophy in many ways. He was remarkable, original, and influential, wrote the opus magnum of Danish jurisprudence (work On Law and Justice) and had life full of twists, both good and bad.

He even chose the time of his death. Ross had kept an ampoule of morphine at home for many years. He had been given this by his friend, doctor Erik Begtrup. On the day of his death, he said goodbye to his closest family and friends (via telephone or letter). During the day both Lone and Strange Ross (Alf's children) visited their father. On the same day Alf Ross recorded a tape and wrote on the box that it was of possible use for a memorial celebration.

43 ROSS, A.: On Law and Justice. London: Stevens \& Sons, 1958, p. 38-50.

44 As Hilaire McCoubrey and Nigel D. White comment, "it is not very surprising that Scandinavian realism originated at the beginning of the twentieth century at a time when the psychological theories of Sigmund Freud were very much in the public eye." McCOUBREY, H. - WHITE, N. D.: Textbook on Jurisprudence. London: Blackstone Press Limited, 1999, p. 178. Similar influence of psychological studies was on representatives of American Legal Realism. See DUXBURY, N.: Patterns of American Jurisprudence. Oxford: Clarendon Press, 1995, p. 126-127.

45 ROSS, A.: Directives and Norms. London: Routledge \& Kegan Paul, 1968, p. 48-49.

46 ROSS, A.: On Law and Justice. London: Stevens \& Sons, 1958, p. 377. 
In the evening of $16^{\text {th }}$ August 1979 Alf Ross injected himself with the morphine. Just as he had soberly analysed his life, his illness and his death were carefully considered and his decision was made in accordance with his scientific, atheistic approach to life. On his bed there was a volume of selected works by Soya, which was opened at the short story 'Karneval i Aalsinge. On his night stand was a hymn book opened at B.S. Ingemann's 'Der står et slot $i$ vesterled' ${ }^{37}$

Saturday $25^{\text {th }}$ August 1979 the family celebrated a small memorial for Alf Ross and listened to the tape that he had recorded. Alf Ross read aloud two poems and having read the poems, short pause followed and after it Alf Ross said "That was it. Thank you for your attention." 48

\section{Bibliography:}

BJARUP, J.: Skandinavischer Realismus: Hägerström - Lundstedt - Olivecrona - Ross (Scandinavian realism: Hägerström, Lundstedt, Olivecrona, Ross). Freiburg i. B. and München: Alber, 1978.

BRÖSTL, A.: Frontisterion. Bratislava: KALLIGRAM, 2009. 328 p. ISBN 978-80-8101-179-5.

COLOTKA, P. - KÁČER, M. - BERDISOVÁ, L.: Právna filozofia 20. storočia. Praha: Leges, 2016. 304 p., ISBN 978-80-7502-134-2.

DUXBURY, N.: Patterns of American Jurisprudence. Oxford: Clarendon Press, 1995. 520 p. ISBN 0-19-825850-X.

EVALD, J.: Alf Ross - a life. Copenhagen: DJØF Publishing, 2014, 374 p. ISBN 978-87-574-2786-8.

HART, H.L.A.: Scandinavian Realism. In: Cambridge Law Journal, 1959, vol. 17, no. 2, p. 233-240.

CHOVANCOVÁ, J. - VALENT, T.: Filozofia pre právnikov (filozoficko-právne aspekty). Bratislava: Univerzita Komenského v Bratislave, Právnická fakulta, 2012. 357 p. ISBN 978-80-7160-337-5.

KELSEN, H.: General theory of law and state. Trans. Anders Wedberg. Cambridge: Harvard University Press, 1945. $516 \mathrm{p}$.

KUBU゚, L. a kol.: Dějiny právní filozofie. Olomouc: UPOL, 2003. 202 p. ISBN 80-244-0466-4.

McCOUBREY, H. - WHITE, N. D.: Textbook on Jurisprudence. London: Blackstone Press Limited, 1999. 304 p. ISBN 9780199584345 .

OLIVECRONA, K.: Becoming a king according to the old Swedish law: The rite of creating a king as a magic act. Lund: Lunds Universitets årsskrift, 1946.

PATTARO, E. - ROVERSI, C.: Legal Philosophy in the Twentieth Century: The Civil Law World. Volume 12, Tome 2: Main Orientations and Topics. Berlin: Springer, 2016. 850 p. ISBN 978-94-007-1478-6.

ROSS, A.: Directives and Norms. London: Routledge \& Kegan Paul, 1968. 188 p.

ROSS, A.: On Law and Justice. London: Stevens \& Sons, 1958. 377 p.

ROSS, A.: Towards a Realistic Jurisprudence. Trans. A. I. Fausbøll. Copenhagen: Munksgaard, 1946. 304 p.

ROSS, A.: Tû-Tû. In: Harvard Law Review, 1957, vol. 70, no. 5, p. 812-825.

SOBEK, T.: Nemorální právo. Praha: Ústav státu a práva, 2010. 423 p. ISBN 978-80-904024-7-8.

SOBEK, T.: Právní myšlení : Kritika moralismu. Praha: Ústav státu a práva, 2011. 620 p. ISBN 978-80-87439-03-6.

WAABEN, K.: Alf Ross 1899-1979: A Biographical Sketch. In: EJIL, 2003, Vol. 14, No. 4, p. 671-674.

47 EVALD, J.: Alf Ross - a life. Copenhagen: DJøF Publishing, 2014, p. 356.

48 Ibid., p. 357. 


\section{Contact information:}

Mgr. Olexij M. Meteňkanyč

olexij.metenkanyc@flaw.uniba.sk

Comenius University in Bratislava, Faculty of Law

Department of Theory of Law and Social Sciences

Šafarikovo nám. č. 6

P. O.BOX 313

81000 Bratislava 1

Slovak Republic 